\title{
System Definition and Analysis: Power Plant Design and Layout
}

\author{
Topical Report
}

May 1996

Work Performed Under Contract No.: DE-AC21 -93 MC30247

\author{
For \\ U.S. Department of Energy \\ Office of Fossil Energy \\ Morgantown Energy Technology Center \\ P.O. Box 880 \\ Morgantown, West Virginia 26507-0880 \\ By \\ Westinghouse Electric Corporation \\ Power Generation Technology Division \\ Engineering Technologies Department \\ 4400 Alafaya Trail, MC 381 \\ Orlando, Florida 32826-2399
}




\section{Disclaimer}

This report was prepared as an account of work sponsored by an agency of the United States Government. Neither the United States Government nor any agency thereof, nor any of their employees, makes any warranty, express or implied, or assumes any legal liability or responsibility for the accuracy, completeness, or usefulness of any information, apparatus, product, or process disclosed, or represents that its use would not infringe privately owned rights. Reference herein to any specific commercial product, process, or service by trade name, trademark, manufacturer, or otherwise does not necessarily constitute or imply its endorsement, recommendation, or favoring by the United States Government or any agency thereof. The views and opinions of authors expressed herein do not necessarily state or reflect those of the United States Government or any agency thereof. 


\section{CONTENTS}

Section

Page

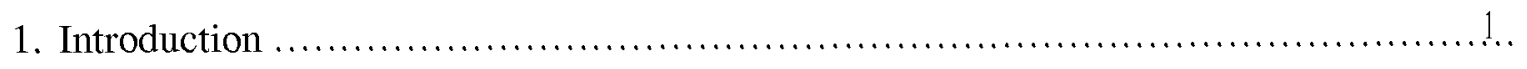

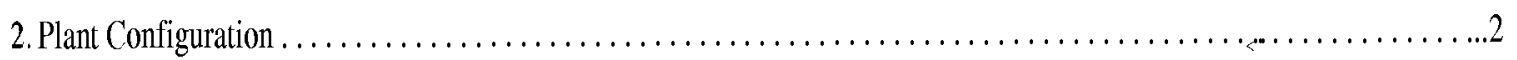

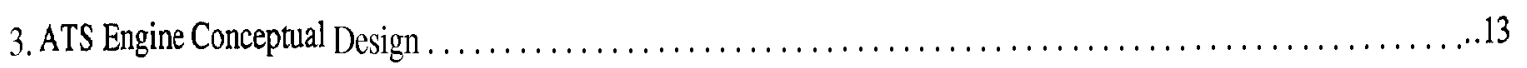

\section{LIST OF FIGURES}

1. Location of Sound Level Measurements .........................................

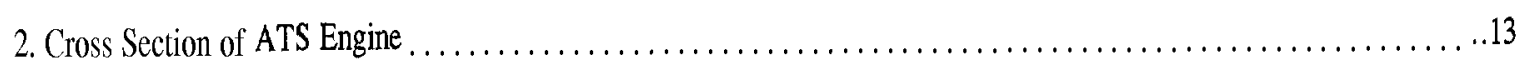

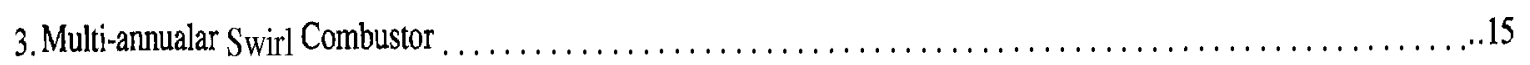

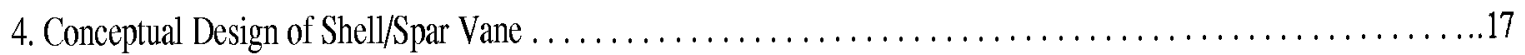

\section{LIST OF APPENDICES}
A. Site Arrangement

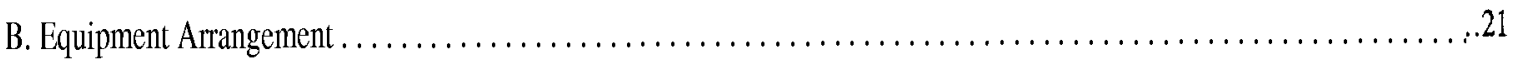

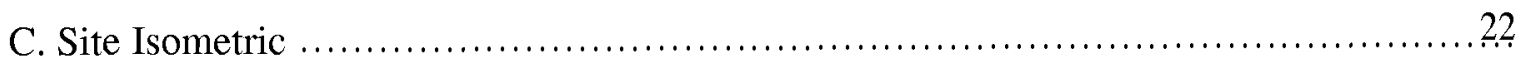




\section{Section 1}

\section{INTRODUCTION}

This is the Topical report for Task 6.0, Phase 2 of the Advanced Turbine Systems(ATS)

Program. The report describes work by Westinghouse and the subcontractor, Gilbert/Commonwealth, in the fulfillment of completing Task 6.0.

A conceptual design for critical and noncritical components of the gas fired combustion turbine system was completed. The conceptual design included specifications for the flange to flange gas turbine, power plant components, and balance of plant equipment. The ATS engine used in the conceptual design is an advanced 300 MW class combustion turbine incorporating many design features and technologies required to achieve ATS Program goals.

Design features of power plant equipment and balance of plant equipment are described. Performance parameters for these components are explained. A site arrangement and electrical single line diagrams were drafted for the conceptual plant.

ATS advanced features include design refinements in the compressor, inlet casing and scroll, combustion system, airfoil cooling, secondary flow systems, rotor and exhaust diffuser. These improved features, integrated with prudent selection of power plant and balance of plant equipment, have provided the conceptual design of a system that meets or exceeds ATS program emissions, performance, reliability-availability-maintainability, and cost goals. 


\section{Plant Configuration}

The Advanced Turbine Systems plant conceptual design and layout is based on a recently completed combined cycle plant design. This state of the art 240-MW 501F Reference Plant incorporates flexible proven design features that minimize design changes usually required to tailor the plant to site specific constraints. The power trains of both plants include one combustion turbine and one multi-pressure steam turbine. The 240MW Reference Plant is a multishaft design. The ATS Plant utilizes a single shaft design with a common generator between the combustion turbine and steam turbine. Both plants are fueled by natural gas and utilize mechanical draft cooling towers. The ATS plant generates considerably more power at a higher efficiency than the 240 MW Reference Plant, mainly because of the increased power and efficiency of the ATS combustion turbine and the higher throttle pressure and reheat temperatures of the steam turbine.

Overall performance parameters for the ATS plant are given in Table 1 at $\operatorname{ISO}\left(59^{\circ} \mathrm{F}, 14.696\right.$ psia \& $60 \%$ relative humidity) conditions:

Table 1

Overall Performance of ATS Plant

\begin{tabular}{|l|c|}
\hline \multicolumn{1}{|c|}{ Performance Parameters } & ATS Plant \\
\hline Approximate Combustion Turbine Power & $290,000 \mathrm{~kW}(\mathrm{e})$ \\
\hline Approximate Steam Turbine Power & $130,000 \mathrm{~kW}(\mathrm{e})$ \\
\hline Approximate Plant Output & $420,000 \mathrm{~kW}(\mathrm{e})$ \\
\hline Net Plant Efficiency, LHV & $>60 \%$ \\
\hline Fuel Type & Natural Gas \\
\hline Cooling Tower & Forced Draft \\
\hline Combustion Turbine Inlet Air Flow & $1,196 \mathrm{lb} / \mathrm{hr}$ \\
\hline Compressor Pressure Ratio & $25: 1$ \\
\hline Approximate Rotor Turbine Inlet Temperature & $2700^{\circ} \mathrm{F}$ \\
\hline Turbine Exhaust Temperature & $1,130^{\circ} \mathrm{F}$ \\
\hline
\end{tabular}




\section{Combustion Turbine}

The combustion turbine of the ATS plant is larger and more efficient than the $501 \mathrm{~F}$ model used in the 240 MW Reference Plant because of its advanced aerodynamic cooling and mechanical design, higher mass flow and firing temperature, and pressure ratio. The gas fuel is preheated, using recovered low-grade heat from the heat recovery steam generator(HRSG). Turbine airfoils are steam-cooled, using higher-grade heat recovered in the bottoming cycle. Additional details of the ATS combustion turbine are given in Section 3. Key combustion turbine parameters of the ATS turbine are shown in Table 1 on the previous page.

\section{Heat Recovery Steam Generator}

The HRSG for the ATS plant is a natural circulation, triple pressure unit with vacuum deaeration. The HRSG configuration allows the addition of duct firing at a later date. Customer requirements often dictate the need for additional steam that duct firing can provide. The duct firing option has the same performance level as the HRSG without the duct firing option in the unfired operational mode. The HRSG will operate over the entire operating range of the combustion turbine. Materials are commercial grade commonly used in boilers today. Design criteria are conventional engineering practice, applying ASME Pressure Vessel Code design guidelines. Key design parameters are given below in Table 2.

Table 2

HRSG Design Parameters

\begin{tabular}{|l|c|}
\hline Performance Parameters & Value \\
\hline Turbine Exhaust Temperature & $1,130 \mathrm{oF}$ \\
\hline CT Exhaust\& Gas Flow & $1,196 \mathrm{lb} / \mathrm{see}$ \\
\hline Number HRSG Pressures & 3 \\
\hline Deaerator Type & Vacuum \\
\hline Approximate HRSG Duty & $1,050 \mathrm{MBtu} / \mathrm{hr}$ \\
\hline HRSG Exhaust Temperature & 207.9 o F \\
\hline
\end{tabular}




\section{Fuel Gas Heater}

Natural gas entering the ATS plant is heated to $800 \mathrm{OF}$ before entering the combustion turbine. This fuel pre-heating is done in two stages: heating with feedwater and heating with CT exhaust. The thermal performance data for the fuel gas heater is tabulated in Table 3:

Table 3

Fuel Gas Heater Performance Data

\begin{tabular}{|l|r|r|}
\hline HEATING FLUID & Feedwater & HRSG Gas \\
\hline Approximate methane flow & $121,000 \mathrm{lb} / \mathrm{h}$ & $121,000 \mathrm{lb} / \mathrm{h}$ \\
\hline Methane inlet temp & $59 \mathrm{oF}$ & $204.3 \mathrm{oF}$ \\
\hline Methane exit temp & $204.3 \mathrm{oF}$ & $800 \mathrm{oF}$ \\
\hline Methane pressure & $500 \mathrm{psia}$ & $500 \mathrm{psia}$ \\
\hline Approximate Water/gas flow & $75,000 \mathrm{lb} / \mathrm{h}$ & $4,500,000 \mathrm{lb} / \mathrm{h}$ \\
\hline Water/gas inlet temp & $271.8 \mathrm{oF}$ & $941.2 \mathrm{oF}$ \\
\hline Water/gas exit temp & $147.4 \mathrm{oF}$ & $903 \mathrm{oF}$ \\
\hline Water/gas pressure & $800 \mathrm{psia}$ & $15 \mathrm{psia}$ \\
\hline Heat duty (Q) & $9.3 \mathrm{MBtu} / \mathrm{h}$ & $47.5 \mathrm{MBtu} / \mathrm{h}$ \\
\hline Mean Temp Diff.(MTD) & $77.5 \mathrm{oF}$ & $349 \mathrm{oF}$ \\
\hline $\begin{array}{l}\text { Approximate Conductance } \\
\text { (UA) }\end{array}$ & $120,000 \mathrm{Btu} / \mathrm{hr}-\mathrm{oF}$ & $136,000 \mathrm{Btu} / \mathrm{hr}-\mathrm{oF}$ \\
\hline
\end{tabular}




\section{Steam Piping}

The main steam piping transfers high-pressure throttle steam from the superheater to the HP turbine inlet. The exhaust from the HP turbine is combined with slightly superheated 1P steam from the HRSG, reheated in the steam-cooled stators of the ATS combustion turbine, then piped to the inlet of the 1P steam turbine. Low-pressure steam piping carries induction steam from the LP superheater to the IP/LP crossover piping.

Piping design, size selection and wall thickness is based uponASMEB31. 1. Pipe sizing remains the same, regardless of duct firing option. Only the wall thickness varies. This philosophy keeps the piping layout and hanger design constant.

The design parameters for the steam piping are listed in Table 4:

Table 4

Steam Piping Design Parameters

\begin{tabular}{|l|c|c|c|c|c|}
\hline $\begin{array}{l}\text { Line } \\
\text { Identifier }\end{array}$ & Main Steam & Cold Reheat & 1P Induction & Hot Reheat & LP Induction \\
\hline From & $\begin{array}{c}\text { HP } \\
\text { Superheater }\end{array}$ & $\begin{array}{c}\text { HP Steam } \\
\text { Turbine }\end{array}$ & $\begin{array}{c}1 \mathrm{P} \\
\text { Superheater }\end{array}$ & $\begin{array}{c}\text { ATS Cooled } \\
\text { Stators }\end{array}$ & $\begin{array}{c}\text { LP } \\
\text { Superheater }\end{array}$ \\
\cline { 3 - 6 } & $\begin{array}{c}\text { HP Steam } \\
\text { Turbine }\end{array}$ & $\begin{array}{c}\text { ATS Cooled } \\
\text { Stators }\end{array}$ & $\begin{array}{c}\text { ATS Cooled } \\
\text { Stators }\end{array}$ & $\begin{array}{c}\text { 1P Steam } \\
\text { Turbine }\end{array}$ & $\begin{array}{c}\text { IP/LP } \\
\text { Crossover }\end{array}$ \\
\hline Line Size & 16 inches & 20 inches & 6 inches & 24 inches & 14 inches \\
\hline $\begin{array}{l}\text { Wall } \\
\text { Thickness }\end{array}$ & 1.75 inches & 0.75 inches & 0.375 inches & 0.875 inches & 0.375 inches \\
\hline Flow & $615,967 \mathrm{lb} / \mathrm{h}$ & $610,707 \mathrm{lb} / \mathrm{h}$ & $55,543 \mathrm{lb} / \mathrm{h}$ & $666,250 \mathrm{lb} / \mathrm{h}$ & $67,032 \mathrm{lb} / \mathrm{h}$ \\
\hline
\end{tabular}




\section{Steam Turbine}

The steam turbine cycle for the ATS plant utilizes a single reheat cycle. The steam turbine exhaust flow of the ATS plant necessitates the use of a double-flow LP exhaust. Operational design parameters include up to 50 starts per year and 8000 hours per year base load operation. Table 5 shows the primary steam turbine performance parameters:

Table 5

\section{Steam Turbine Performance Parameters}

\begin{tabular}{|l|c|}
\hline Performance Parameters & Value \\
\hline Approximate S/T Power & $130,000 \mathrm{~kW}(\mathrm{e})$ \\
\hline Approximate S/T Throttle Flow & $616,000 \mathrm{lb} / \mathrm{hr}$ \\
\hline Approximate S/T Throttle Temperature & $1,050 \mathrm{oF}$ \\
\hline Approximate S/T Throttle Pressure & $1,800 \mathrm{psig}$ \\
\hline S/T Exhaust Flow Type & Double Flow \\
\hline Number Reheat Passes &... \\
\hline
\end{tabular}

\section{Generator-Exciter}

The combustion turbine and steam turbine are on a single shaft. Both turbines share a common hydrogen cooled generator. Generator design will be conventional design. Dimensions for the generator are:

. length of generator and exciter is611 inches, with a width of 174 inches

. height above foundation is 137 inches

. depth below foundation is 40 inches

\section{Condenser/Cooling Tower}

The ATS plant steam turbine requires a double flow back end, For design convenience, a side entry saddlebag condenser was modeled rather than a conventional vertical type. The saddlebag condenser imposes a lower height and shorter overall length requirement on the building. A tabular listing of performance parameters for the condenser and cooling tower is shown in Table 6. 
Table 6

Condenser Performance Parameters

\begin{tabular}{|l|c|}
\hline Performance Parameters & ATS Plant \\
\hline S/T Exhaust Flow Type & Double Flow \\
\hline Condenser Duty & $700.4 \mathrm{MBtu} / \mathrm{hr}$ \\
\hline Cooling Tower Type & Mechanical Draft \\
\hline Cooling Tower Cells at Design & 8 Cells \\
\hline
\end{tabular}

\section{Site Arrangement}

The arrangement of generation equipment and peripheral equipment needed at the plant site is shown in the Site Arrangement drawing(see Appendix A). Peripheral balance-of-plant equipment includes:

An 8-cell cooling tower

. A 1.8-million-gallon (3-day supply) fuel storage tank

. A 1.5-million-gallon (3-day supply) condensate storage tank

. A 1.5-million-gallon (3-day supply) demineralized water storage tank

. Provisions for other optional equipment

The footprint of the plant measures $828^{\prime}$ by $682^{\prime}$. The ATS Plant layout is also shown in the Site Isometric drawing(see Appendix C).

\section{Generation Equipment Layout}

The layout of the generation equipment reflects the single-shaft arrangement of the HRSG, combustion turbine, generator, and steam turbine. The low-pressure steam turbine is flanked by twin side-entry saddlebag condensers. The plan view of the primary power generation equipment is shown in the Equipment Arrangement drawing(see Appendix B).

\section{$\underline{\text { Plant Costs and RAM }}$}

Plant costs and reliability-availability-maintainability is discussed in detail in Topical Report Task 3.0. This report was submitted December 1994. 


\section{Plant Control Design Basis}

The Powerlogic II control system is built around the Westinghouse Distributed Processing Family(WDPF), comprising of a broad range of compatible building blocks. All functions of the combustion turbine, generator, HRSG and supporting plant equipment are controlled by this system. Programmable logic controllers are used for vendor supplied subsystems(i.e., water treatment, fuel washing, etc.), when they are stand alone packages. The primary design goal of the control system is fault tolerance, no single component failure will impair nor degrade the availability of the turbine/generator.

The basic system consists of the following equipment: Distributed Processing Units(DPU), an Engineers Console(ECON), data logging system and printer. An additional cabinet, the local panel, contains the video display, keyboard, rack mounted modules(i.e., vibration monitor, UV flame detector, counters, timers, synchroscope, etc) and local operator controls. All subsystems are linked together on a redundant high speed serial interface called the Westnet II Data Highway.

Each DPU contains redundant control processors and the capacity for 36 field input/output(I/O) circuit cards. Various 1/0 cards are used to interface with field devices. All 1/0 cards provide "on card" signal processing, calibration and fault diagnostics. The DPU is powered with $125 \mathrm{VDC}$ and incorporates redundant power supplies for both, the control processors and the $1 / 0$ card cages. Field redundancy is achieved with multiple sensors and controls which are interfaced to separate 1/0 circuits within the DPU 1/0 section. Fault tolerance through redundancy is achieved with redundant sensors/controls or with various tests for process variable limits and sensor signal reasonableness.

\section{$\underline{\text { Static Start System }}$}

Westinghouse combustion turbines prior to ATS, relied upon a separate large motor, or "starting motor", to accelerate the combustion turbine until sufficient torque became available after ignition. The ATS design eliminates the starting motor and replaces it with a static variable speed drive to "motor" the generator. The Static Start System includes the static start variable speed drive equipment, the static start excitation equipment, the DC link reactor, and the static start isolation transformer. The generator design is slightly modified to accommodate motoring and the harmonics due to the variable speed drive. The Static Start System can be configured to enable the starting of one or more turbine-generator sets. The drive output and field excitation are automatically controlled to maintain a constant volts-per- hertz output. This control feature with built in protection allows the drive output to be directly connected to the generator step up transformer without concern for over-excitation at low frequencies. During the start up process, breakaway torque is provided by the DC motor driven turning gear to accelerate the turbine from zero rpm to 2 or $3 \mathrm{rpm}$ where the automatic control system initiates the start up sequence. The Static Start System performs its starting functions by operating the generator as a synchronous motor and does this by applying a varying frequency voltage to the 
generator stator, while adjusting the field excitation, to accelerate the turbine-generator system to a speed suitable for turbine ignition to take place. After ignition, the drive continues to help the turbine accelerate to its self-sustaining speed. The static start system is also sized to run continuously and can be used to spin cool the turbine-generator system during shutdowns for maintenance and therefore reduce the outage time.

\section{$\underline{\text { Inlet System }}$}

The side inlet air duct directs ambient air into the compressor inlet air manifold. Instrumentation, filter cleaning aids, the compressor wash system, anti-icing equipment and turning vanes are included inside the inlet air system. The ambient air is filtered before entering

the compressor. A parallel baffled silencer is provided for sound attenuation purposes.

The compressor inlet air manifold is shaped to provide an efficient flow pattern into the axial flow compressor, Provisions for an evaporative air cooler is included, should the customer select this option.

\section{Exhaust Stack}

After combustion, expanding exhaust gases pass through the transition, then into the plenum of the exhaust stack. Turning vanes located in the exhaust stack efficiently direct the gases vertically. Parallel baffles in the exhaust stack attenuate gas borne noise. For heat recovery applications, the exhaust gases are directed to the heat recovery steam generator before exiting the exhaust stack.

\section{Cooling Water Design Basis}

Cooling water is circulated throughout the plant by the Circulating Water System. The Circulating Water system delivers and returns water for the main condenser, cooling tower and the auxiliary cooling system. The auxiliary cooling system supplies and returns cooling water for the turbine, generator hydrogen coolers, lube oil coolers, turbine electrohydraulic coolers, compressor aftercoolers, boiler feed pump coolers and sample station coolers. 
Two vertical wet pit centrifugal $50 \%$ capacity pumps are furnished in the cooling tower pump intake structures. A stationary trash screen removes debris before it can enter the vertical pumps. Underground piping consists of prestressed concrete pipe, aboveground piping consists of carbon steel piping.

Each circulating water pump discharge valve opens automatically as a part of the pump startup sequence. The pumps and piping are protected from water hammer and reverse rotation by discharge valves and a vacuum breaker. The circulating pump is not allowed to run dry, should the level in the intake structure water level be too low, the pump will trip.

\section{System Acoustics Design Basis}

\section{Near Field Sound Levels}

The near field A-weighted sound level resulting from the operation of the Westinghouse supplied Equipment in a free-field environment, when measured around the source envelope contour, as shown in Figure 1, is expected to be an average of $90 \mathrm{~dB}(\mathrm{~A})$ or less when measured at a horizontal distance of 3 feet from major equipment surfaces at a height of 5 feet above the ground when operated at steady state conditions at the rated load, exclusive of transients, pulse filter cleaning (if applicable), startup and shutdown, off normal and emergency conditions.

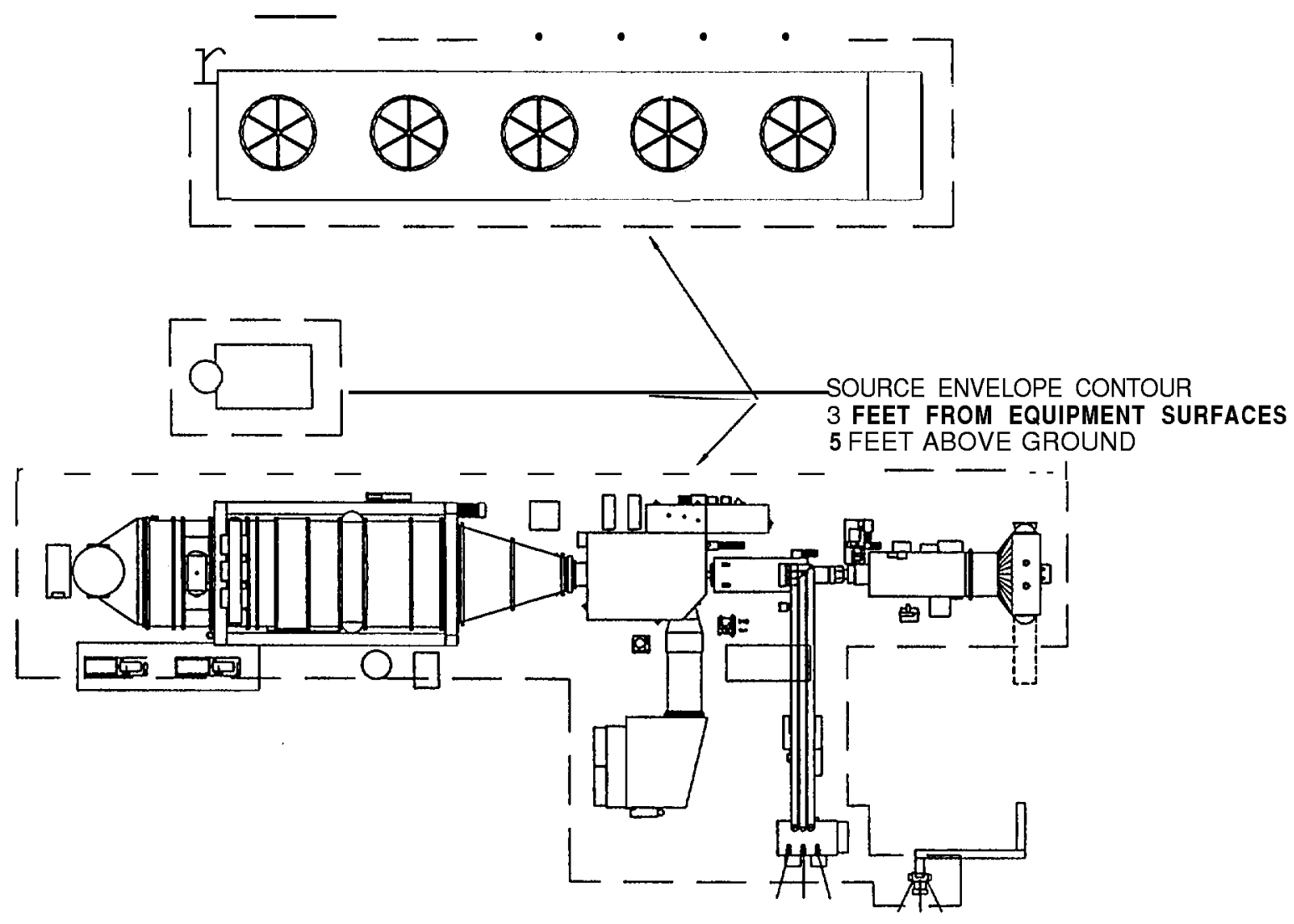

Figure 1 Location of Sound Level Measurements 


\section{Far Field Sound Levels}

The far field A-weighted sound level resulting from the operation of the Westinghouse supplied Equipment at steady state conditions at the rated plant load is expected to be an average of 75 $\mathrm{dB}(\mathrm{A})$ when measured at a distance of 400 feet from the equipment source envelope, (smallest rectangle enclosing the plant) at a height of 5 feet above ground level in a free-field environment. Sound levels are exclusive of background ambient and any transients, pulse filter cleaning, startup and shutdown, off normal and emergency conditions.

The following factors could influence and have an impact on the actual far field sound levels:

1. Site topography

2. Influence of solid obstacles, such as buildings, walls, etc.

3. Ground cover and vegetative growth.

4. Ambient air conditions, such as temperature, pressure and humidity.

5. Background noise levels.

The above factors must be considered when determining the final site specific far field Aweighted sound levels.

\section{Sound Level Compliance Testing}

All acoustic compliance testing will be based on the principles defined in the Westinghouse Sound Test Principles Document, 21 T5672. This document generally conforms to recognized industry standards such as ANSI B 133.8 and ISO 6190. The sound test procedure will define the environmental correction factors, test measurement uncertainty and instrumentation tolerance correction factors consistent with that defined in ANSI B 133.8 and 1S0 6190.

\section{Fuel Gas System Design Basis}

The fuel gas system receives, regulates, heats, and transports natural gas supplied from the natural gas supply pipeline, at the site boundary to the combustion turbine. The fuel gas system consists of two subsystems, the fuel gas skid and the fuel gas supply system.

Natural gas is supplied to the fuel gas supply system by a natural gas pipeline to a single connection location at the plant boundary. A separate uninterruptible gas supply header may supply gas for space conditioning purposes. Both lines must be metered separately. Separate shutoff valves and duplex strainers are provided in the gas supply piping and the uninterruptible gas supply header.

A fuel gas heater is provided for heating the fuel gas supply. Heated water from the HRSG feedwater system is used to heat the fuel gas. A liquid separator/leak detector is installed downstream of the fuel gas heater to detect any leaking water. Upon detection of a water leak, the heater isolation valves will close and a bypass valve will open to isolate the heater. This design insures no water will enter the fuel gas skid and consequently the combustion turbine where significant damage can occur. 
Gas pressure is regulated on the fuel gas skid by control valves. A double block and bleed valve arrangement is provided to ensure positive isolation of the fuel gas from the combustion turbine. A shutoff valve is provided for quick closure of the gas supply to prevent overspeed conditions. The fuel gas skid contains a filter that removes last traces of noncondensibles/particulates before they enter the turbine.

In the event the gas supply pressure is less than 425 psig at the site boundary, a fuel gas booster compressor must be provided to satisfy the combustion turbine fuel gas pressure requirements. 


\section{Section 3}

\section{ATS Engine Conceptual Design}

A conceptual design was carried out to define the preliminary configuration of the ATS engine (see Figure 1 below). The ATS engine is an advanced 300 MW class design incorporating many proven design features used in previous Westinghouse gas turbines and new design features and technologies required to achieve the ATS Program goals. The compressor design philosophy is based on that used in the advanced $501 \mathrm{G}$ compressor. The combustion system uses 16 combustors of lean-premixed multistage design. Closed-loop steam cooling is used to cool the combustors and transitions. The four-stage turbine design is an extension of the advanced 501G turbine design, employing 3D design philosophy and advanced viscous analysis codes. To further enhance ATS plant efficiency, the turbine airfoils are closed-loop cooled.

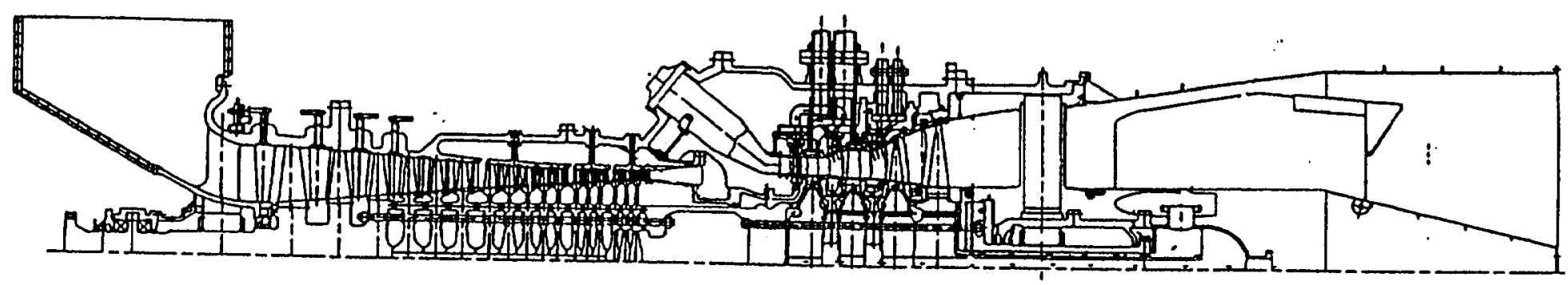

Figure 2 Cross Section of ATS Engine 
Inlet

The compressor inlet is through side entry. The inlet casing, incorporating the front engine supports, is the scroll bellmouth type. The bellmouth surface profile is generated with the aid of a 3D viscous code to ensure optimum surface velocity distributions, and hence minimum inlet losses. The flow path surfaces of the inlet casing, which is a nodular iron casting, are coated with a ceramic coating to provide a smooth surface finish and, and therefore, further reduce the inlet losses and improve the velocity profile into the compressor.

\section{$\underline{\text { Compressor }}$}

The ATS compressor design pressure ratio is 25:1. The design philosophy is based on that used in the advanced $501 \mathrm{G}$ compressor, but with additional design enhancements such as the incorporation of brush seals to minimize leakage under the stator shrouds. Advanced aerodynamic design tools and controlled diffusion design process are employed in order to minimize loss and maximize airfoil loading. In addition, airfoil thickness is reduced to the minimum allowable from mechanical considerations to reduce diffusion and shock losses. Abradable coatings are applied to the outer shroud to minimize blade tip clearances. As a result of the 25:1 pressure ratio, variable stators are incorporated in the front stages to improve starting and part-load operation,

The front- and middle-stage compressor discs are made of conventional material forgings. Due to the increased compressor exit air temperature in the ATS application Ni-based alloy disc material is used in the back stages. The compressor rotor is joined to the turbine rotor through a torque tube. The front part of the compressor cylinder, which is horizontally split (as are all the other engine cylinders), is made of cast steel. Blade rings, which are intermediate cylinders, are used in the back end to minimize eccentricity and hence blade tip clearances. The blade rings are made of $2-1 / 2 \% \mathrm{Cr}-1 \%$ Mo low alloy steel. The compressor blades, which are attached to the discs by a dove tail root design, are made of 17-4 $\mathrm{PH}$ and $12 \% \mathrm{Cr}$ steels. The stators are made of similar material as the blades and all, except for the variable stators, are fabricated into diaphragms.

\section{$\underline{\text { Combustion System }}$}

The combustion system incorporates 16 can-annular combustors of lean-premixed multistage design with catalytic components as necessary to meet emissions requirements and ensure good stability. Figure 2 shows the multi annular swirl ultra low NOX combustor, which is one of the candidate combustors for the ATS engine. To obtain less than 10 ppmvd NOX emissions, nearly all of the compressor delivery air must be premixed with the fuel. Therefore, closedloop steam cooling is used to cool the combustors and transitions, which duct the hot combustion gases into the turbine. The cooling stream is supplied and extracted through manifolds located on the stage 1 and 2 turbine blade ring.

Conventional Ni-based sheet materials are used in the manufacture of the combustors and transitions, 
(․)
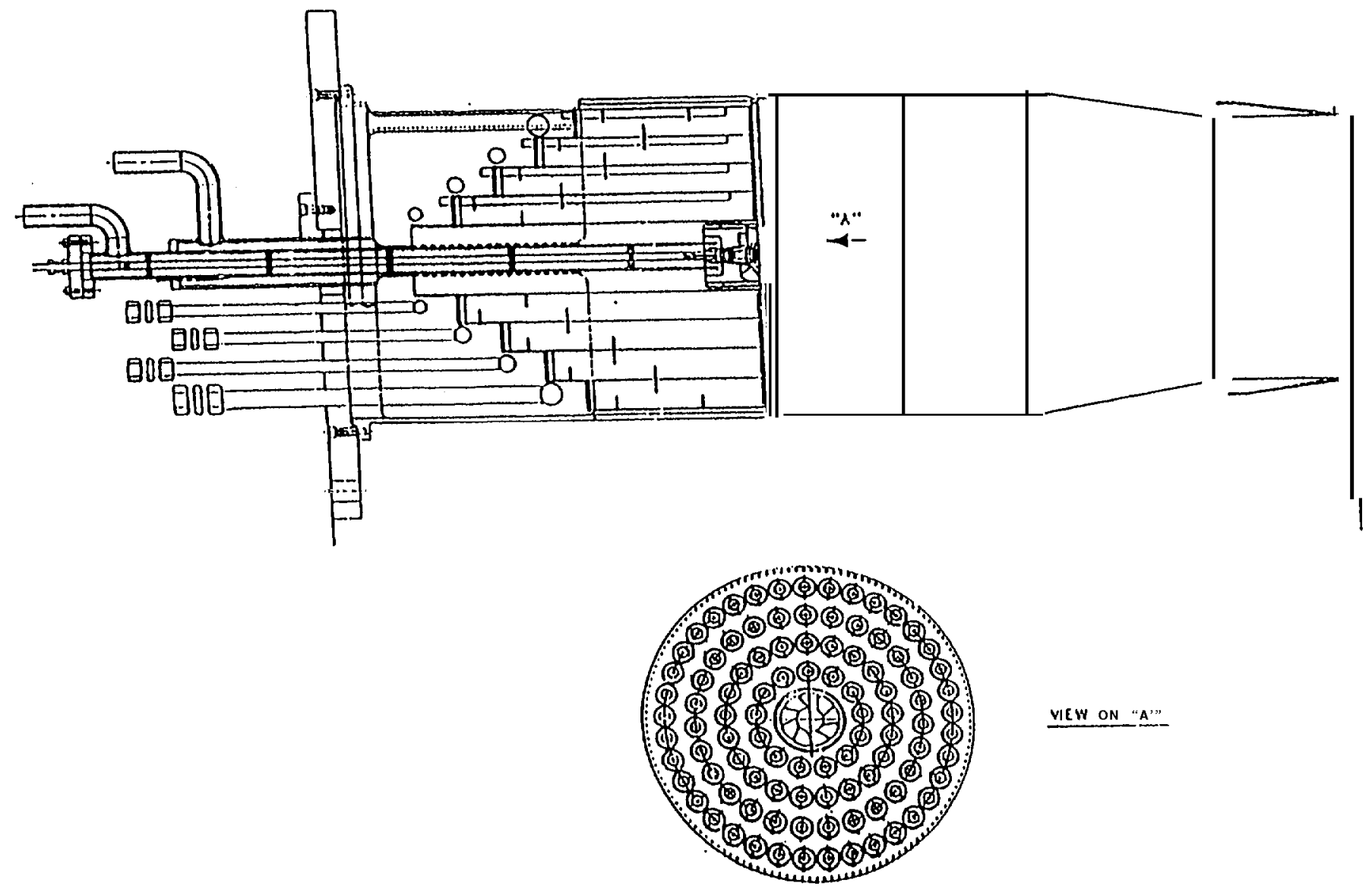

Figure 3 Multi -annular Swirl Combustor 


\section{$\underline{\text { Turbine }}$}

The ATS turbine is an extension of the advanced four-stage turbine designed for the $501 \mathrm{G}$ engine. The $501 \mathrm{G}$ turbine efficiency was increased over that of $501 \mathrm{~F}$ by applying 3D design philosophy and advanced viscous analysis codes. The airfoil loadings were increased above previous levels to optimize airfoil efficiency while minimizing airfoil solidity. The reduced airfoil solidity resulted in reduced cooling requirements and enhanced plant efficiency. The ATS turbine design incorporates the following additional enhancements: closed-loop cooling of vanes and blades, blade tip clearance control on the first two stages, and airfoil clocking (optimum circumferential alignment of airfoils in downstream stage with respect to those in the upstream stage.

To improve plant efficiency closed-loop steam cooling (CLSC) is used to cool some turbine airfoils. The heat capacity of steam is almost double that of air. Less steam than air is thus required to cool the turbine components. The major benefit of CLSC is the elimination of cooling air ejection into the flow path. This results in an increase in gas temperatures downstream of the first-stage vane and hence an increase in gas energy level during the expansion process. A secondary benefit is the elimination of mixing losses associated with cooling air ejection into the gas path. The combination of the above effects results in a significant increase in ATS plant efficiency. In addition, the NOX emissions are reduced because more air is available for lean-premix combustor at the same burner outlet temperature.

Achieving acceptable blade metal temperatures in a closed-loop cooling design is a challenge due to the absence of cooling air film to shield the turbine airfoil and shroud wall, and no shower-head or trailing edge ejection to provide enhanced cooling in the critical leading and trailing edge regions. To produce an optimized closed-loop cooling design, the following approaches are utilized: (1) airfoil aerodynamic design tailored to provide minimum gas side heat transfer coefficients, (2) minimum coolant inlet temperature, (3) thermal barrier coating applied on airfoil and end wall surfaces to reduce heat input, (4) maximized cold side surface area, (5) turbulators to enhance cold side heat transfer coefficients, and (6) minimum outside wall thickness to reduce wall temperature gradients and hence the internal heat transfer coefficients required to cool the airfoil.

The shell/spar cooling concept will be considered for cooling stage 1 vanes and blades (see Figure 3). This concept consists of a cast airfoil-shaped support structure (spar) around which a thin sheet of superalloy (shell) is diffusion bonded. The outside surface of the spar incorporates chordwise grooves that form small, closely spaced cooling channels under the shell. Thus, the shell/spar configuration achieves the desired qualities of a thin outside wall and a favorable cold-to-hot surface area ratio. The airfoil spar contains three cavities: the fore and aft cavities supply the cooling steam, and the midcavity discharges the spent cooling steam. Cooling channels extend in a chordwise direction from a supply cavity to the discharge cavity. Holes drilled through the spar connect the cooling channels with the cavities. The trailing edge is cooled by spanwise holes.

Recent advances in casting technology have produced cooling configurations with thin outside walls and internal cooling passages suitable for CLSC. To increase cold-side heat transfer, turbulence promoters can be incorporated in the cooling channels. The peripheral radial cooling hole concept will also be evaluated, 


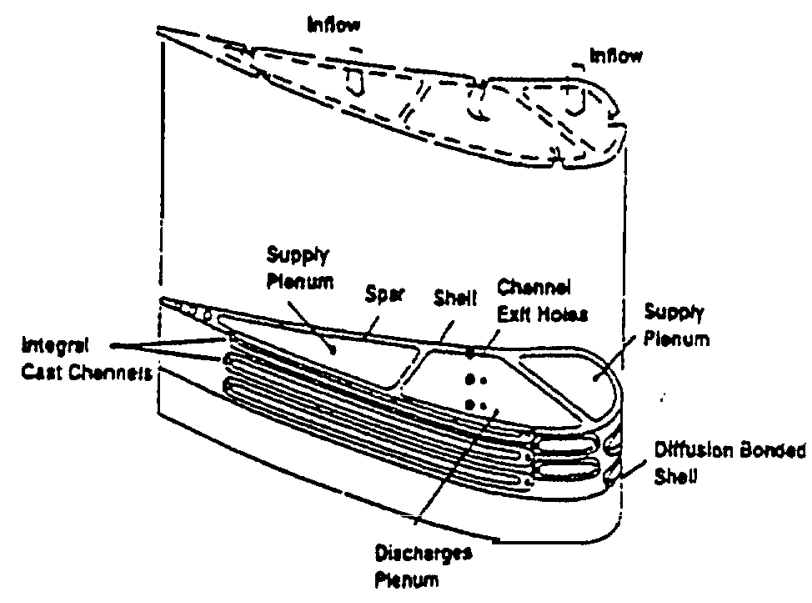

Figure 4 Conceptual Design of SheII/Spar Vane

The heat load on stage 2 vanes will permit steam-impingement-cooled castings to be used. Impingement cooling will be applied to the airfoil fore and aft cavities, with convection cooling via spent stream return flow in the midcavity. Heat load on the stage 2 blade will also permit a conventional serpentine cooling design. The stage 3 vane will use a serpentine cooling design. Stage 4 airfoils will be uncooled.

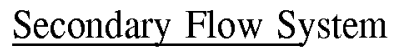

The engine secondary flow system consists of air and steam flows. These two fluids are isolated from each other and supplied to the proper locations with minimum leakage. Airflow from the compressor exit passes through the torque tube seals and cools the front face of the row 1 turbine disc. This air is then cascaded through the rotating rotor to the stage 2 interstage region to prevent entry of hot gas in front of and behind the stage 2 vane. Air leakage is reduced by using brush seals in the critical sealing areas.

Cooling steam is supplied to the stationary parts through pipes passing through the turbine cylinder and into a circular manifold. Reheated steam is returned through a similar manifold/piping system. Pipes are connected to the manifolds by flanges with piston ring seals, which seal tightly and accommodate thermal growth. The system is designed to provide parallel cooling steam flow to stage 1,2 , and 3 vanes.

The steam flow system for the rotating blades consists of an inlet manifold at the turbine end of the rotor shaft; a rotating axial annular passage inside the rotor shaft that conducts steam from the manifold area to the discs; a series of holes and slots in the rotor discs to supply steam from the rotating passage to the roots of the cooled blades; another series of holes and slots in the discs to carry the reheated steam from the blades to a hole in the center of the rotor discs; and finally, a steam exhaust from this center bore into a plenum at the rotor stub end. 


\section{$\underline{\text { Rotor System }}$}

The turbine rotor is constructed from a series of individual turbine discs, spacer discs, and a stub shaft attached by a single set of spindle bolts and weldments. The turbine discs are of conventional design, except for a rotor bore used as a steam passage and the additional downstream blade groove sealing hardware. Ni-based components are used, as required, to cater to the exhaust steam temperature.

\section{$\underline{\text { Exhaust Diffuser }}$}

The ATS engine has an axial exhaust diffuser similar to that used in previous Westinghouse designs. It consists of the exhaust cylinder and an exhaust manifold. The exhaust cylinder carries the hot end journal bearing, which is contained in the front part of the inner tailcone. This portion of the tailcone is supported by tangential or radial struts, This strut system allows for thermal expansion without changing the bearing centerline location. The struts are protected from the hot gases by airfoil type shielding. The exhaust manifold has two access ports for lube oil, seal air, and steam piping. One of the ports has provision for accessing the hot end bearing. The materials used in the exhaust are Ni-based sheet metals.

\section{Turbine Bearings}

The bearing design being used for the ATS combustion turbine is almost identical to the design used on the W501 G. The turbine rotor bearings consist of two journal bearings and one thrust bearing. The journal bearings are a four pad tilting pad arrangement with offset pivots and preloaded upper pads. The lower two pads are chromium/copper for better heat dissipation while the upper two normally unloaded pads are steel. The lower pads are provided with thermocouples to monitor the bearing babbitt temperature during operation. This basic bearing configuration has been used by Westinghouse for many years and on several different frames. Because the pad loads are not excessively high, an oil lift system is not normally used. The thrust bearings consist of a twelve pad configuration that utilizes offset pivots and directed lubrication, The pads on both the active side and the inactive side are steel, which could be changed to chromium/copper, if the thrust load becomes significant. The thrust bearings are also supplied with thermocouples to monitor the bearing babbitt temperature during operation, as well as load cells to measure the total thrust load on the initial engine. Both bearings require 150 SSU turbine oil.

\section{$\underline{\text { Lubrication System }}$}

The lubrication system provides clean, filtered oil at the required temperature and pressure to the steam turbine bearings, combustion turbine bearings and generator seal oil system and generator journal bearings. The principle components of the lubrication system are located in the Mechanical Package, situated adjacent to the combustion turbine.

A heat exchanger for cooling the lube oil is mounted on the Mechanical Package roof. Inside the mechanical package resides the oil resevoir, valves, piping, instrumentation, vents and supporting hardware, A vacuum extractor on the lube oil resevoir provides a partial vacuum for the bearing housings to minimize oil leakage to the outside. 
The turbine/generator is designed with safeguards built into the controls to prevent catastrophic bearing failures due to loss of lubricating oil. Starting equipment is interlocked so that the combustion turbine cannot be rotated without adequate lubricating oil pressure. The main AC motor driven lube oil pump must be energized before the combustion turbine starting sequence can begin.

A DC motor driven backup lube oil pump is provided for fail safe operation. Two AC motor driven vertically mounted centrifugal lube oil pumps are provided for redundancy. One AC lube oil pump supplies all needed oil for normal operation. Only one AC lube oil pump is running during normal combustion turbine operation. The second $\mathrm{AC}$ lube oil pump will start should maintenance of pressure becomes a problem. In the event both $\mathrm{AC}$ lube oil pumps cannot maintain lube oil pressure, the combustion turbine trips, and the DC lube oil pump starts. The DC lube oil pump permits safe operation during the shutdown and subsequent turning gear operation. 


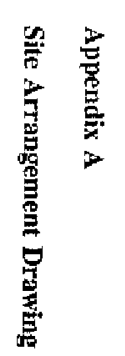

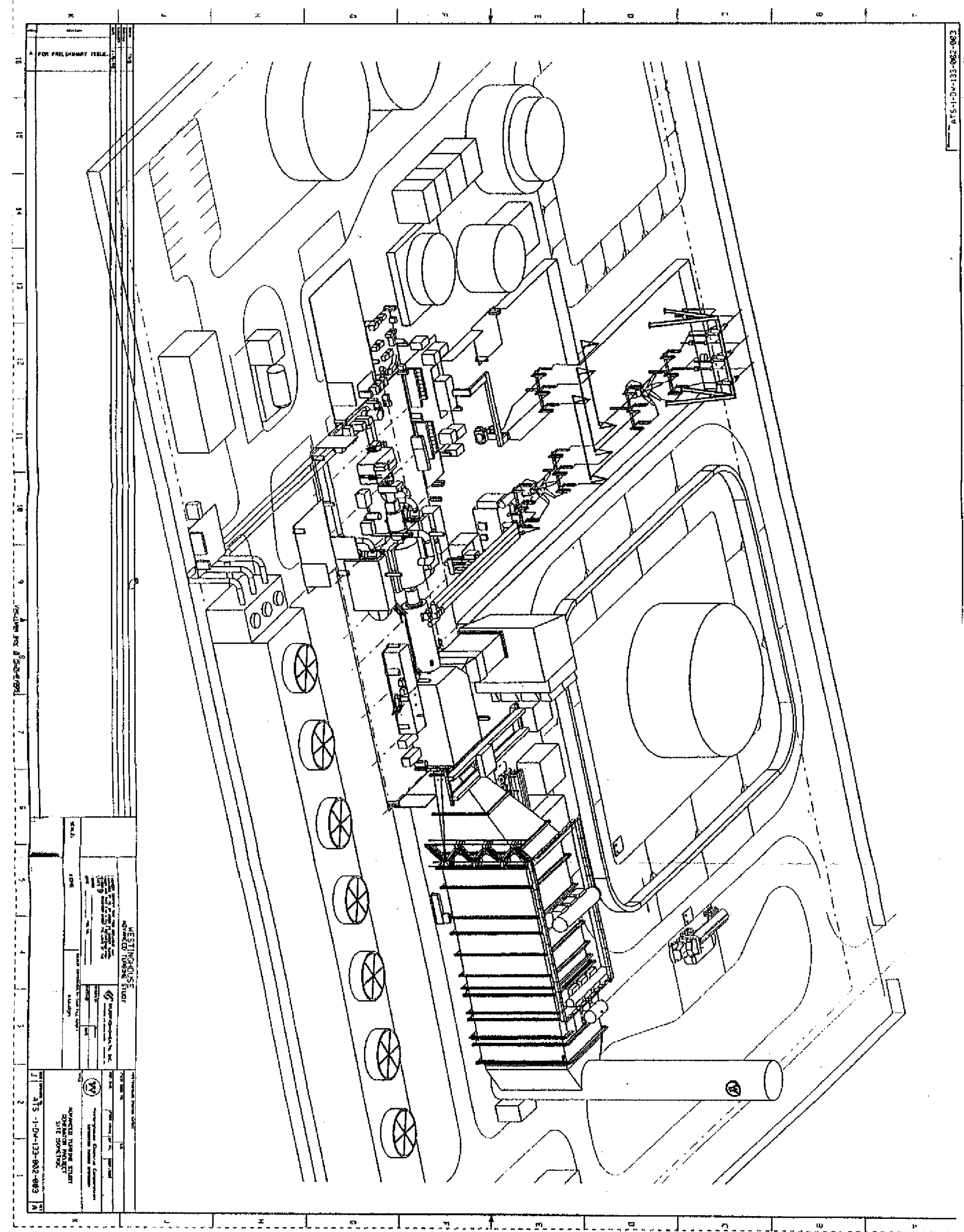



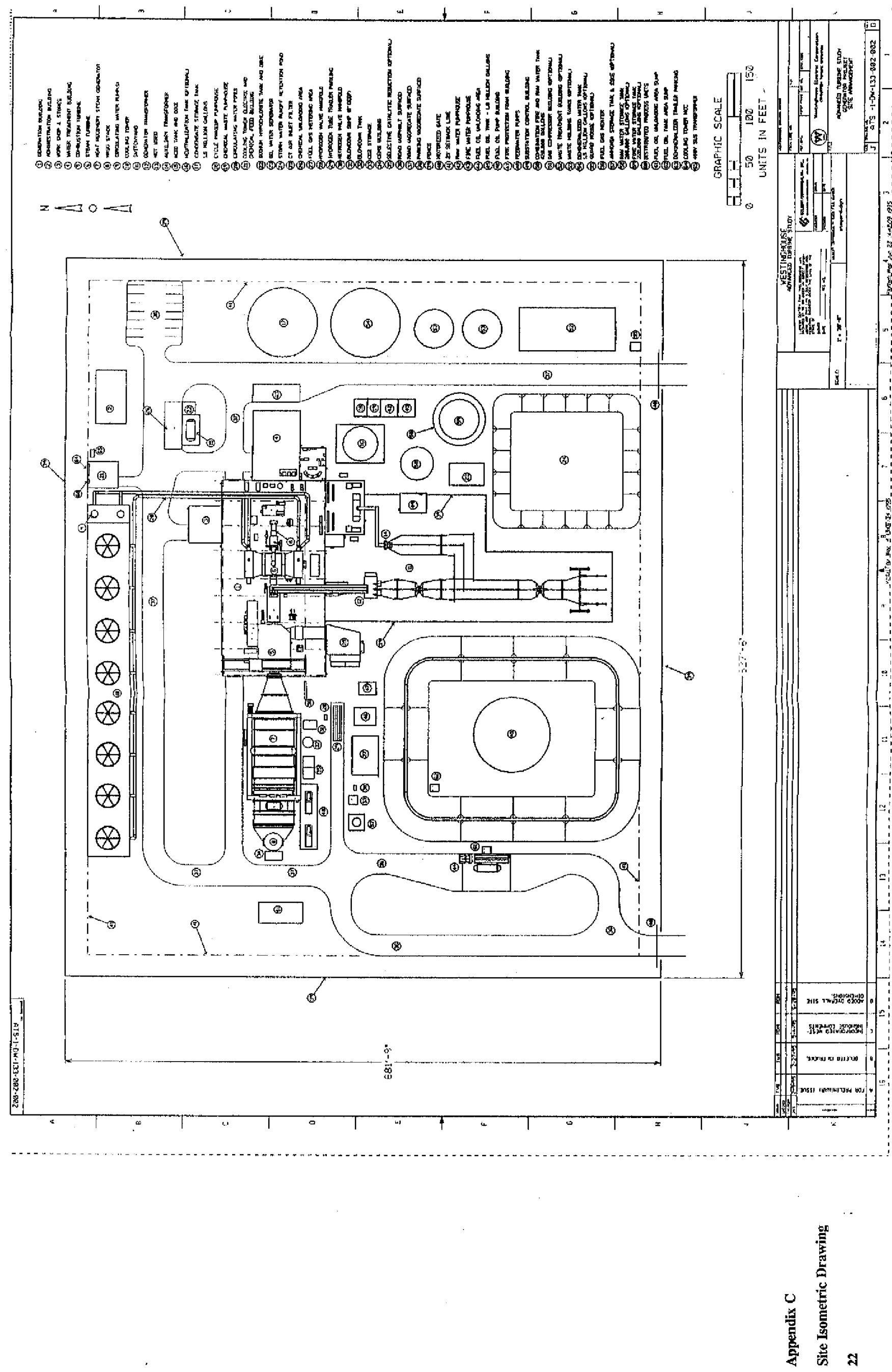